\title{
Reliability Evaluation Method with Weibull Distribution for Temporary Overvoltages of Substation Equipment
}

\author{
Shigemitsu Okabe Senior Member (Tokyo Electric Power Company) \\ Toshihiro Tsuboi Member (Tokyo Electric Power Company) \\ Jun Takami Member (Tokyo Electric Power Company)
}

Keywords: electric power equipment, power-frequency withstand voltage test, Weibull distribution, reliability evaluation, V-t characteristic

The Japanese standard of high voltage testing, JEC-0102-1994, specifies the "lightning impulse withstand voltage test" and the "power-frequency withstand voltage test" for electric equipments. As for the "power-frequency withstand voltage test", the "longduration power-frequency withstand voltage test" has applied for an effective grounding system of $187 \mathrm{kV}$ and above. Test voltages are evaluated with power fequency voltage and temporary overvoltage on electric equipments and the lifetime reliability, using Weibull distribution function.

The reliability evaluationg method by Weibull distribution function was widely recognized in study of power frequency withstand voltage for JEC-0102 establishment in 1994. There were some discussions about the Weibull distribution technique in those days. However, the question about reliability estimating with the Weibull distribution was left after the issue of JEC-0102.

Lately, investigation for the revison of JEC-0102 standard has carried out. The main targets of the revison is the tests for un-effective grounding system, which had not been revised in JEC0102-1994. In connectiong with that, the questions about the reliability estimation method by Weibull distribution technique have been again raised about the case that the differnt voltages are applied one after another.

The reliability estmation method used for JEC-0102 (hereinafter, "the conventional method" and "Method I" in figures) is independent of past failure hysteresis at the time of changing volatge. With regards to the method, it is necessary to verify the validity of adapting the failure probability distribution from time 0 each time of applying voltages.

On the other hand, another model ("Method II" in figures) which retaines cumulative fault probability was proposed. The model shifts the V-t characteristic to another with the relationship that $V^{\mathrm{n}} t$ is equal at the time of changing volatge. Moreover, the other method ("Method III" in figures) of adjusting a failure frequency density function was proposed recently. This method sets the failure probability " 1 " at the infinite time applying voltage and fulfills the condition of the power low in the V-t characteristics of equipments.

The present paper first discusses the physical meanings of the various kinds of evaluating methods and secondly examines their effects on the "power-frequency withstand voltage test". Further, an appropriate method is investigated for an oil-filled transformer and a gas insulated switchgear with taking notice of dielectric breakdown or partial discharge mechanism under various insulating material and structure conditions. The following results were obtained int this paper.

(1) The physical meaniings of three kinds of reliability estimation methods were clarified, and the failure probability density function and ccumulative failure probability under each voltage were formulized. The conventional method is reasonable for the independent failure phenomenon. The other methods proposed recently should be used for the phenomenon of accumulation of failure progress.

(2) Based on the above result, the formula of the short-duration part of the "long-duration power-frequency withstand voltage test" was formulized in terms of consideration of plural voltages applied. Futher, the influence of the Weibull parameter values on the test voltage were evaluated by trial calculations. Under the condition of the time shape parameter "a" of being smaller than 1 , the conventional method gave the highest test voltage.

(3) The tentative conclusion gives that the conventional method would be most pertinent under the present conditions in order to evaluate reliability of an oil-filled transformer and a gas insulated switchgear.

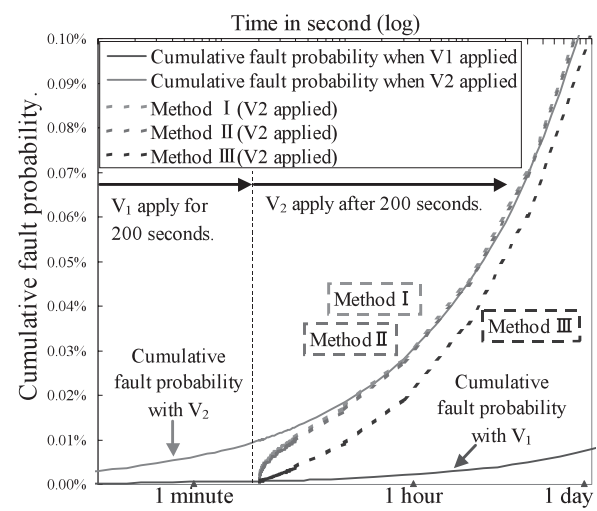

Fig. 1. Cumulative fault probability given by reliability evaluation method in case of $\mathrm{V} 1<\mathrm{V} 2(\mathrm{a}=0.39)$

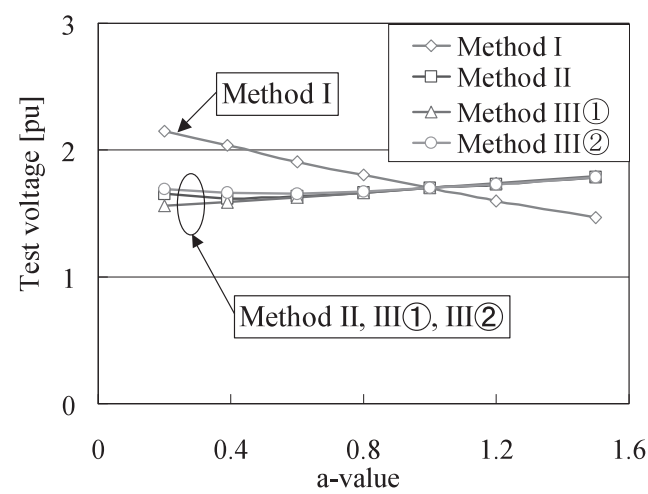

Fig. 2. Trial calculation of test voltage with changing avalue by reliability evaluation method (m: constant) 


\title{
ワイブル分布を用いた変電機器の交流短時間過電圧 に対する信頼度評価
}

\author{
上級会員 岡部 成光* 正 員 坪井 敏宏* \\ 正員高見 潤*
}

\section{Reliability Evaluation Method with Weibull Distribution for Temporary Overvoltages of Substation Equipment}

Shigemitsu Okabe*, Senior Member, Toshihiro Tsuboi*, Member, Jun Takami*, Member

\begin{abstract}
The power-frequency withstand voltage tests are regulated on electric power equipment in JEC by evaluating the lifetime reliability with a Weibull distribution function. The evaluation method is still controversial in terms of consideration of a plural number of faults and some alternative methods were proposed on this subject. The present paper first discusses the physical meanings of the various kinds of evaluating methods and secondly examines their effects on the power-frequency withstand voltage tests. Further, an appropriate method is investigated for an oil-filled transformer and a gas insulated switchgear with taking notice of dielectric breakdown or partial discharge mechanism under various insulating material and structure conditions and the tentative conclusion gives that the conventional method would be most pertinent under the present conditions.
\end{abstract}

キーワード：電力機器，商用周波耐電圧試験，ワイブル分布，信頼度評価， V-t 特性

Keywords: electric power equipment, power-frequency withstand voltage test, Weibull distribution, reliability evaluation, V-t characteristic

\section{1. はじめに}

電力機器の絶縁仕様として, 一般に「雷インパルス耐電 圧試験」と「商用周波耐電圧試験」が JEC-0102「試験電圧 標準」(1) で規定されている。このうち $187 \mathrm{kV}$ 以上の有効接 地系では「商用周波耐電圧試験」として「長時間商用周波耐 電圧試験」が規定され，使用期間中の常規電圧と $1 \mathrm{LG}$ 時 · 負荷遮断時などの短時間過電圧に対する所要の絶縁性能を 検証する。この試験電圧の設定に当たっては, 機器に加わ る常規電圧・過電圧と試験電圧を, ワイブル分布を用いて 評価し信頼度を検証する(2)。

ワイブル分布による信頼度評価法は, 1988 年の電気協同 研究第 44 巻 3 号「絶縁設計の合理化」(3) で広く認知され, その後 1994 年の JEC-0102 (1) で採用された。その間，本手 法の是非に関していくらか議論があったが(4)(5)，その後は実 務的なニーズの機会が無かったこともあり，議論や検討は 沈静化していた。最近になり, 取り残されていた非有効接 地系の合理化を含めて JEC-0102 改定の動きがあり，再び

\footnotetext{
*東京電力 (株) 技術開発研究所

干 230-8510 横浜市鶴見区江ヶ崎町 4-1

High Voltage \& Insulation Group, R\&D Center, TEPCO

4-1, Egasaki-cho, Turumi-ku, Yokohama 230-8510
}

ワイブル分布による信頼度評価法で特に複数の電圧レベル が混在する場合に対して課題が提起された ${ }^{(6) \sim(8)}$ 。

本報告では，短時間過電圧を長時間商用周波耐電圧試験 の短時間部で評価することを対象とし，最初に複数の電圧 レベル混在時のワイブル評価の各種手法を物理的意味と対 応付けて整理し, 次に各手法の試験電圧レベルへの影響を 試算した。更に, 電力機器の各種絶縁媒体・絶縁構造に対 し, 絶縁破壊または部分放電の開始および進展メカニズム から，適切な評価法を検討した。

\section{2. ワイブル分布による信頼度評価法}

〈2·1〉 信頼度評価法の基礎概念 恋圧器や GIS を代 表とする機器の絶縁要素の絶縁破壊や部分放電開始の電圧一 時間特性（V-t 特性）は, $V^{\mathrm{n}} t=\mathrm{K}$ （一定）で良く近似され る。電圧 $V$ を時間 $t$ 印加した場合の累積故障確率 $P$ (無部 分放電確率 $R$ ) は一般にワイブル分布に従い, さらに“ $V V^{\mathrm{n}} t$ ” が一つの変数である ${ }^{(5)}$ とすると次式で表される ${ }^{(9)}$ 。

$P=1-\exp \left(-\mathrm{A} V^{\mathrm{m}} t^{\mathrm{a}}\right)$

$\mathrm{A}$ : 定数, $\mathrm{a}$ ：時間形状パラメー夕, $\mathrm{m}$ : 電圧形状 パラメータ

次に, 機器に印加される電圧 (常規運転電圧, 短時間過 電圧など）に対する試験電圧の信頼度評価法について示す。 
(1) 式より試験電圧（変数のサブスクリプト $\mathrm{t}$ ）と，過電圧 などの機器印加電圧（変数のサブスクリプト s)における信 頼度 $R(=1-P)$ を表す式の比を取ると次式が得られる。

$$
V_{\mathrm{t}}^{\mathrm{m}} T_{\mathrm{t}}^{\mathrm{a}}=V_{\mathrm{s}}^{\mathrm{m}} T_{\mathrm{s}}^{\mathrm{a}} \frac{\ln R_{\mathrm{t}}}{\ln R_{\mathrm{s}}}
$$

(2) 式に機器の絶縁特性から得られるワイブルパラメー 夕 $\mathrm{n}, \mathrm{m}, \mathrm{a}$ 值と, 寿命期間に想定される過電圧㧍よび常規 運転電圧の条件 $V_{\mathrm{s}}, T_{s}$ 㧍よび試験中の信頼度 $R_{\mathrm{t}}$ を与えて, 運転期間に期待される信頼度 $R_{\mathrm{s}}$ を満足する試験電圧值 $V_{\mathrm{t}}$ と試験時間 $T_{\mathrm{t}}$ を設定する。上記の評価法は, 電気協同研究 「絶縁設計の合理化」(3) で広く認知され，現行の JEC-0102 「試験電圧標準」(1) の信頼度評価の根拠となっている評価法 である。本論文では，このうち短時間過電圧を長時間商用 周波耐電圧試験の短時間部で評価することを対象とする。 常規対地電圧と長時間部の評価は, 絶縁要素の V-t 特性取 得時の物理現象との等価性を別途検討する必要性があると 考える。

以上は電圧印加が 1 回の場合の，基本的な考え方である。 次に電圧を複数回印加した場合の故障確率の考え方につい て述べる。試験電圧の評価法としての検討は 3 章に記すが,

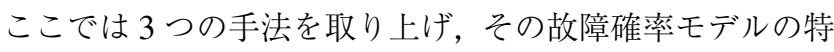
徵・物理的な意味について述べる。

JEC-0102で採用されている評価法 (本稿では以下, 独立 事象法（従来法）と呼ぶ）では, 各々の事象が履歴に関係 なく独立であると考えるが，毎回時間 0 からの故障確率分 布に従うことの是非などの課題を含んでいる(7)。これに対 し, 電圧が変化した場合には, 累積故障確率が保存される ように, “ $V n t ”$ ”゙等しい V-t 特性上に移行するモデル（本稿 では以下，累積故障法と呼ぶ）が提案された ${ }^{(10)}$ 。また，最 近, 無限大時間印加時の故障確率が 1 となり, 機器の V-t 特性が $\mathrm{n}$ 乗則を満たす条件で, 時間 0 からの確率密度関数 を補正する方法（本稿では以下，残存確率法と呼ぶ）が提 案されている(7)。

$\langle\mathbf{2} \cdot \mathbf{2}\rangle$ 電圧を複数回印加した場合の評価手法 前述 の 3 種の評価法について, 異レベル電圧が 2 回印加された 場合の累積故障確率 $P$, 故障確率密度関数 $f$ は文献 (8) に 整理されている。ここでは, $P, f$ の定式化と 2 種の電圧レ ベル印加時の故障確率密度関数のイメージを表 1 に示す。 故障確率密度関数は，ワイブル分布の時間形状パラメー夕 $\mathrm{a}$ が $\mathrm{a}<1$ と $\mathrm{a}>1$ について, 電圧 $V_{1}$ を時間 $T_{1}$ 印加した 後に電圧 $V_{2}\left(V_{1}>V_{2}\right)$ を印加した場合について示す。前 提として, 機器の V-t 特性が $\mathrm{n}$ 乗則を満たし， ワイブル分 布の $\mathrm{n}, \mathrm{m}, \mathrm{a}$ 值が $V, t$ に依らず一定である場合を対象と している。

（1）方法 I〈独立事象法 (従来法)〉電圧の印加毎に 時間 0 からの故障確率密度分布に従うモデルである。これ は，毎回の事象が履歴に関係なく独立しており，いわゆる エージングや劣化などの影響が無いとするモデルである。

電圧を 2 回印加した場合の累積故障確率 $P$ は, 1 回目と 2 回目の電圧印加による故障確率をそれぞれ $P_{1}, P_{2}$ とした
場合 $P=1-\left(1-P_{1}\right) \cdot\left(1-P_{2}\right)$ と表現される。すなわち

$$
P=1-\exp \left\{-\mathrm{A} V_{1}^{\mathrm{m}} T_{1}^{\mathrm{a}}-\mathrm{A} V_{2}^{\mathrm{m}}\left(t-T_{1}\right)^{\mathrm{a}}\right\} .
$$

となる。

簡単な例えとして，100 個の試料に電圧 $V_{1}$ を時間 $T_{1}$ 印 加した後に $V_{2}$ を印加した場合の累積故障確率を考えると する。独立事象法 (従来法) は, $V_{1}$ を $T_{1}$ 印加して 100 個中 80 個が残存した場合に, 時刻 $T_{1}$ から新たに 80 個の試料を 用意し， $V_{2}$ を印加して累積故障確率を求める方法である。

（2）方法 II〈累積故障法〉 “ $V{ }^{\mathrm{n}} t$ ”が等しいストレス は, 設備に等しい影響を与えるとして, 累積故障確率を保 存するようにストレスが累積すると考えるモデルである。

数式上では, 印加電圧が $V_{2}$ となる時刻 $T_{1}$ 以降の確率密 度関数について, 時間 0 からの $V_{2}$ 印加の確率密度関数を 時間 $s_{1}$ により補正するモデルである。

先の例えでは， $V_{1}$ を $T_{1}$ 印加して 100 個中 20 個故障し た場合に，時刻 0 から新たに 100 個の試料に $V_{2}$ を印加し て 20 個壊れた時刻を $T_{1}{ }^{\prime}\left(=s_{1}\right)$ とする。この時刻を $T_{1}$ とみなして, $T_{1}$ 以降の $V_{2}$ 印加時の累積故障確率を求める 方法である。

（3）方法 III〈残存確率法〉残存確率を一致させる ことにより先行印加電圧の履歴を残したモデルである。

数式上では, 時間 0 から電圧 $V_{2}$ を印加した故障確率密 度関数に $\exp \left(-\mathrm{A} V_{1}^{\mathrm{m}} T_{1}^{\mathrm{a}}\right) / \exp \left(-\mathrm{A} V_{2}^{\mathrm{m}} T_{1}^{\mathrm{a}}\right)$ を乗じて補正した モデルである。 $\exp \left(-\mathrm{A} V_{1}^{\mathrm{m}} T_{1}^{\mathrm{a}}\right)$ とは, 電圧 $V_{1}$ を時間 $T_{1}$ 印 加した場合の残存確率であり, 無限大時間経過時の累積故 障確率が 1 となるように, 電圧 $V_{2}$ 印加時の確率密度関数 を補正する。

先の例えでは, $V_{1} を T_{1}$ 印加して 100 個中 80 個が残存 した場合に， $V_{2}$ を $T_{1}$ 印加して 100 個中 40 個が残存する ならば，時刻 0 から新たに $200(=100 \times 80 / 40)$ 個の試料 に $V_{2}$ を $T_{1}$ 印加して, 80 個が残存する時刻 $T_{1}$ 以降より $V_{2}$ 印加時の累積故障確率を求める方法である。

上記のモデルを絶縁物のイメージに照らし合わせると， 絶縁破壊現象が進展を開始しても印加電圧が除去されると 印加前の状態に復帰する場合には, 独立事象法 (従来法) が 想定される。逆にある種の固体絶縁物における絶縁破壊又 カニズムのように, トリーが進展し電圧除去後も元の状態 に復帰しない場合には, 累積故障法の想定に近いと考えら れる。

\section{3. 信頼度評価法と試験電圧}

$\langle\mathbf{3} \cdot \mathbf{1}\rangle$ 累積故障確率と信頼度評価式 2 章の表 1 に示 した各手法の累積故障確率 $P$ について, 大きさの異なる電圧 を2 回印加した場合の累積故障確率の時間変化のイメージを 図 1 に示す。ワイブルパラメータ值は $\mathrm{n}=30, \mathrm{~m}=11.75$, $\mathrm{a}=0.39^{(3)}$ とし,$V_{1}<V_{2}\left(V_{1}=1.00 \mathrm{pu}, V_{2}=1.25 \mathrm{pu}\right)$ と $V_{1}>V_{2}\left(V_{1}=1.25 \mathrm{pu}, V_{2}=1.00 \mathrm{pu}\right)$ の各々の場合に ついて試算した結果を示す。 $V_{1}$ 印加中の期間 $\left[0 \sim T_{1}\right]$ は, どの計算法でも同一の特性である。絶縁物性で一般に現れ 


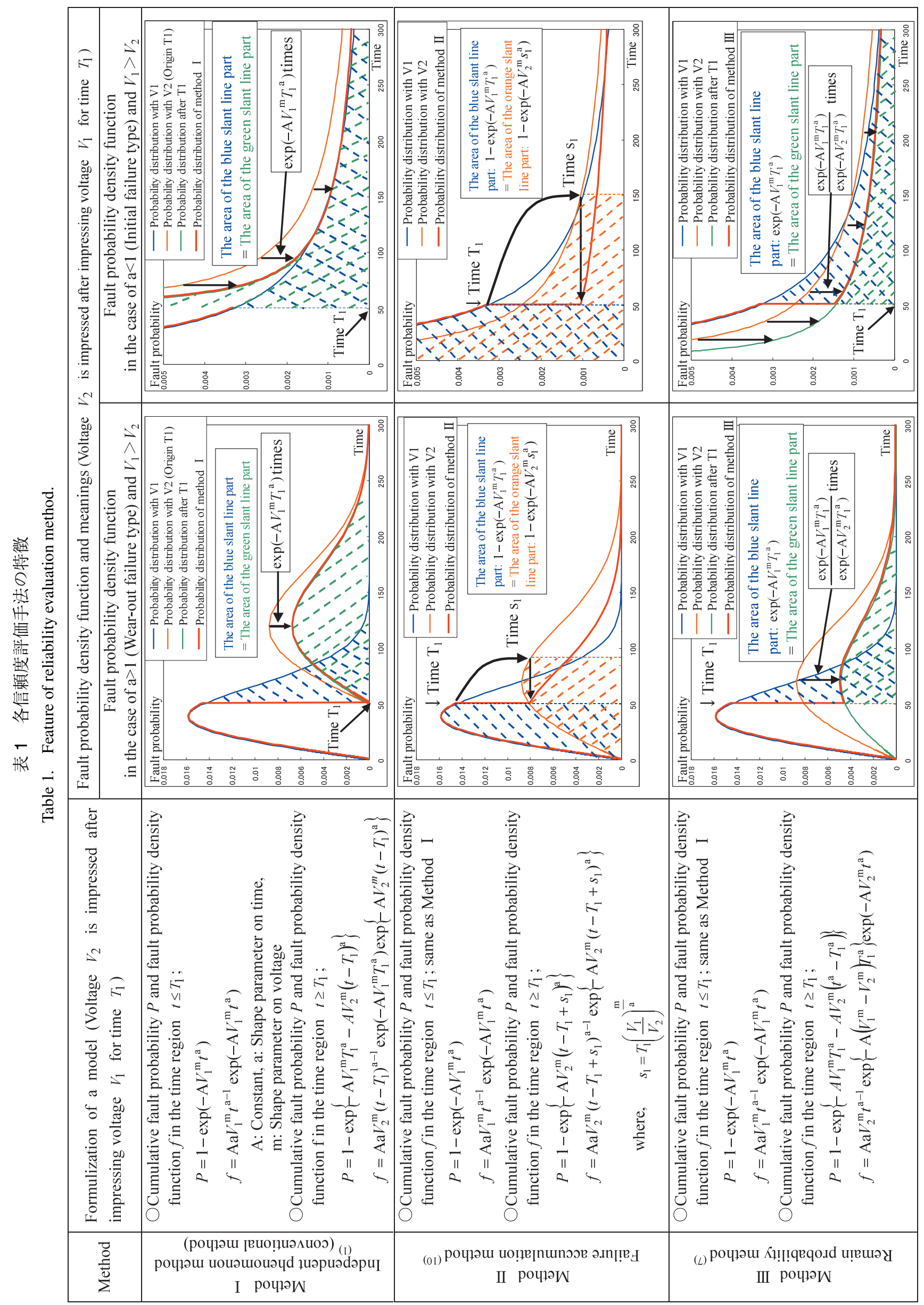




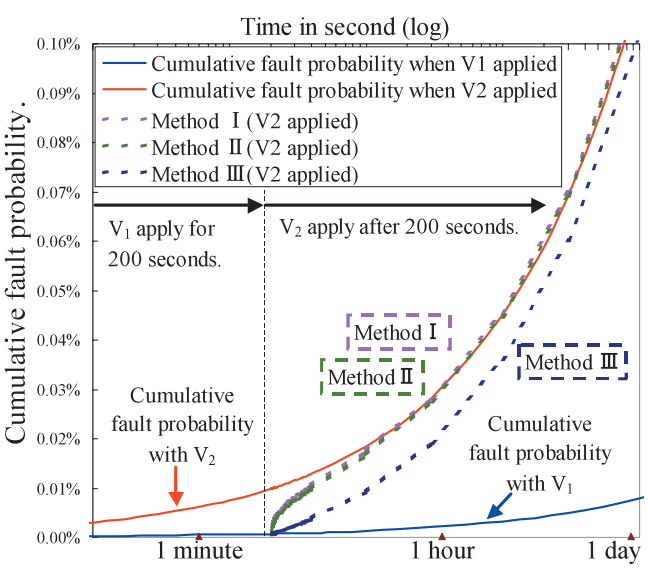

(a) In case of $V_{1}<V_{2}$

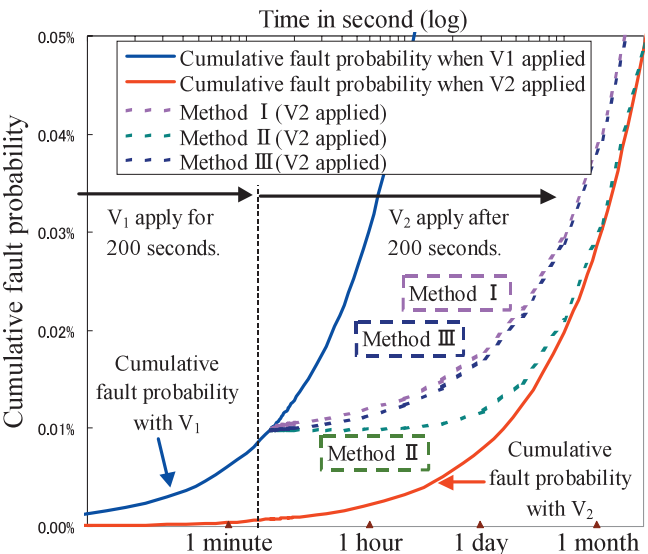

(b) In case of $V_{1}>V_{2}$

図 1 各信頼度評価法による累積故障確率の特性 $(\mathrm{a}=0.39)$

Fig. 1. Cumulative fault probability given by reliability evaluation method $(\mathrm{a}=0.39)$.

ることの多い $\mathrm{a}<1$ の場合の累積故障確率は，時間 0 付近 の高い故障確率を累積する独立事象法（従来法）が最も高 い。残存確率法については，高い電圧が先行する場合には 累積故障法よりも高く，低い電圧が先行する場合には累積 故障法よりも低い。また， a > 1 の場合の累積故障確率は， $\mathrm{a}<1$ の場合と 3 つのモデルの大小関係が逆転し，独立事 象法（従来法）が最も低い。

次に 2 章に示した故障確率モデルによる信頼度評価式を 表 2 に示す。前提として，機器の V-t 特性が $\mathrm{n}$ 乗則を満た し，ワイブル分布の $\mathrm{n}, \mathrm{m}, \mathrm{a}$ 值が $V, t$ に依らず一定であ る場合を対象とする。試験電圧，時間を $\left[V_{t}, T_{t}\right]$ とし，N 回 の過電圧および継続時間を $\left[V_{i}, T_{i}\right](\mathrm{i}=1,2,3, \ldots \mathrm{N})$ とし て，累積故障確率と信頼度評価の一般式を示した。

累積故障確率を表わす式からもわかる様に，各々のモデ ルは無限大時間経過時の累積故障確率が 1 となる。また, それぞれ想定している時間領域は異なるが，印加電圧に対 して V-t 特性の $\mathrm{n}$ 乗則に従う。 $\mathrm{a}=1$ の場合には，3つの モデルの累積故障確率は等しい。独立事象法 (従来法), 累 積故障法の信頼度評価值は，電圧印加の順番や時刻が変化 した場合でも，印加電圧と印加時間の組み合わせが同じ場
表 2 各信頼度評価法の試験電圧計算式

Table 2. Calculation equation on test voltage of reliability evaluation method.

\begin{tabular}{|c|c|}
\hline Method & Calculation equation of reliability evaluation \\
\hline 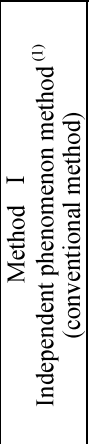 & $\begin{array}{l}\begin{array}{l}O \text { Cumulative fault probability defined as } P_{\mathrm{t}} \text { during } \\
\text { voltage test and as } P_{\mathrm{s}} \text { during overvoltage defined; }\end{array} \\
P_{\mathrm{t}}=1-\exp \left\{-\mathrm{A} V_{\mathrm{t}}^{\mathrm{m}} T_{\mathrm{t}}^{\mathrm{a}}\right\} \\
P_{\mathrm{s}}=1-\exp \left\{-\mathrm{A} \sum_{i=1}^{N}\left(V_{i}^{\mathrm{m}} T_{i}^{\mathrm{a}}\right)\right\} \\
\text { Equation of reliability evaluation } \\
V_{\mathrm{t}}^{\mathrm{m}} T_{\mathrm{t}}^{\mathrm{a}}=\left\{\sum_{i=1}^{N}\left(V_{i}^{\mathrm{m}} T_{i}^{\mathrm{a}}\right)\right\} \frac{\ln \left(1-P_{\mathrm{t}}\right)}{\ln \left(1-P_{\mathrm{s}}\right)} \\
\operatorname{EEquation~for~short~time~part~voltage~of~long~time~}_{\text {power-frequency withstand voltage test }} \\
V_{\mathrm{t}}^{\mathrm{m}} T_{\mathrm{t}}^{\mathrm{a}}=\left(N_{1} V_{1}^{\mathrm{m}} T_{1}^{\mathrm{a}}+N_{2} V_{2}^{\mathrm{m}} T_{2}^{\mathrm{a}}\right) \frac{\ln \left(1-P_{\mathrm{t}}\right)}{\ln \left(1-P_{\mathrm{s}}\right)}\end{array}$ \\
\hline 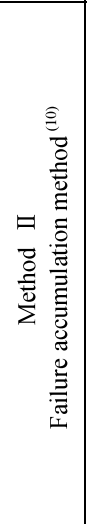 & $\begin{array}{l}\text { OCumulative fault probability defined as } P_{\mathrm{t}} \text { during } \\
\text { voltage test and as } P_{\mathrm{s}} \text { during overvoltage defined; } \\
P_{\mathrm{t}}=1-\exp \left\{-\mathrm{A} V_{\mathrm{t}}^{\mathrm{m}} T_{\mathrm{t}}^{\mathrm{a}}\right\} \\
P_{\mathrm{s}}=1-\exp \left\{-\mathrm{A}\left(\sum_{i=1}^{N} T_{i} V_{i}^{\frac{\mathrm{m}}{\mathrm{a}}}\right)^{\mathrm{a}}\right\} \\
\text { Equation of reliability evaluation } \\
V_{\mathrm{t}}^{\mathrm{m}} T_{\mathrm{t}}^{\mathrm{a}}=\left(\sum_{i=1}^{N} T_{i} V_{i}^{\frac{\mathrm{m}}{\mathrm{a}}}\right)^{\mathrm{a}} \frac{\ln \left(1-P_{\mathrm{t}}\right)}{\ln \left(1-P_{\mathrm{s}}\right)} \\
\text { Equation for short time part voltage of long time } \\
\text { power-frequency withstand voltage test } \\
V_{\mathrm{t}}^{\mathrm{m}} T_{\mathrm{t}}^{\mathrm{a}}=\left(N_{1} T_{1} V_{1}^{\frac{\mathrm{m}}{\mathrm{a}}}+N_{2} T_{2} V_{2}^{\frac{\mathrm{m}}{\mathrm{a}}}\right)^{\mathrm{a}} \frac{\ln \left(1-P_{\mathrm{t}}\right)}{\ln \left(1-P_{\mathrm{s}}\right)}\end{array}$ \\
\hline 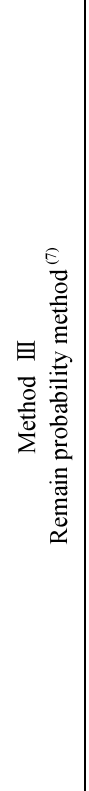 & $\begin{array}{l}\text { OCumulative fault probability defined as } P_{\mathrm{t}} \text { during } \\
\text { voltage test and as } P_{\mathrm{s}} \text { during overvoltage defined; } \\
\text { ( Final time when the } N \text { th voltage } V_{N} \text { is } \\
\left.\text { impressed: defined as } T_{t_{N}}\right) \\
P_{\mathrm{t}}=1-\exp \left\{-\mathrm{A} V_{\mathrm{t}}^{\mathrm{m}} T_{\mathrm{t}}^{\mathrm{a}}\right\} \\
P_{\mathrm{s}}=1-\exp \left[-\mathrm{A} V_{N}^{\mathrm{m}} T_{\mathrm{t} N}^{\mathrm{a}}-\mathrm{A} \sum_{i=1}^{N}\left\{\left(V_{i-1}^{\mathrm{m}}-V_{i}^{\mathrm{m}}\right) T_{\mathrm{t}(i-1)}^{\mathrm{a}}\right\}\right] \\
\text { Equation of reliability evaluation (Final time when } \\
\text { the } N \text {-th voltage } V_{N} \text { is impressed: defined as } \\
\left.T_{t N}\right) \\
V_{\mathrm{t}}^{\mathrm{m}} T_{\mathrm{t}}^{\mathrm{a}}=\left[V_{N}^{\mathrm{m}} T_{\mathrm{t} N}^{\mathrm{a}}+\sum_{i=1}^{N}\left\{\left(V_{i-1}^{\mathrm{m}}-V_{i}^{\mathrm{m}}\right) T_{\mathrm{t}(i-1)}^{\mathrm{a}}\right\}\right] \frac{\ln \left(1-P_{\mathrm{t}}\right)}{\ln \left(1-P_{\mathrm{s}}\right)} \\
\quad \text { Where, } T_{t 0}=0, V_{0}=0 \\
\text { Equation for short time part voltage of long time } \\
\text { power-frequency withstand voltage test } \\
V_{\mathrm{t}}^{\mathrm{m}} T_{\mathrm{t}}^{\mathrm{a}}=\left\{V_{2}^{\mathrm{m}}\left(N_{1} T_{1}+N_{2} T_{2}\right)^{\mathrm{a}}+\left(V_{1}^{\mathrm{m}}-V_{2}^{\mathrm{m}}\right)\left(N_{1} T_{1}\right)^{\mathrm{a}}\right\} \frac{\ln \left(1-P_{\mathrm{t}}\right)}{\ln \left(1-P_{\mathrm{s}}\right)} \\
\text { As cumulative fault probability varies according to } \\
\text { order of voltages applied, cases are divided as } \\
\text { follows; } \\
\text { Method III (1): Lower voltage is first applied. } \\
\text { Method III (2): Higher voltage is first applied. }\end{array}$ \\
\hline
\end{tabular}

合には評価值は同じ結果となる。電圧 $V_{1}, V_{2}$ が加わる期 間 $T_{1}, T_{2}$ により評価值が一意に決定される。残存確率法 については，電圧印加時刻や順序によって評価結果が相違 し, 高い電圧が先行して印加される場合と，低い電圧が先 行する場合を評価値の上下限とする特徵を有する。

$\langle\mathbf{3 \cdot 2 \rangle}$ 試験電圧試算結果の比較 表 2 に示した $3 つ$ の試験電圧評価式により, 変圧器の短時間部の商用周波試 験電圧值を評価した結果を図 2 に示す。 


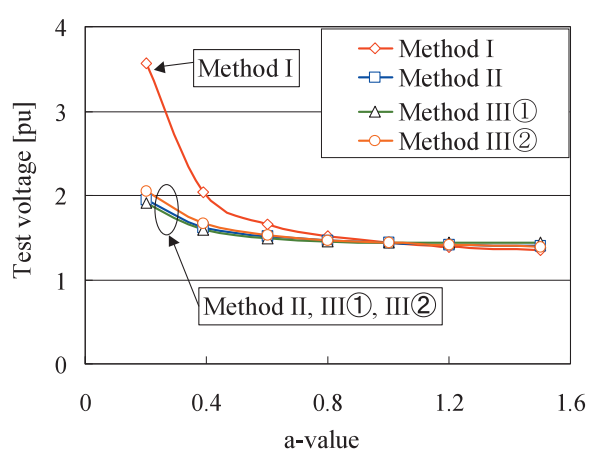

Test voltage for a-value [pu]

\begin{tabular}{|c|c|c|c|c|c|c|c|}
\hline a-value & 0.2 & $\mathbf{0 . 3 9}$ & 0.6 & 0.8 & 1.0 & 1.2 & 1.5 \\
\hline \hline Method I & 3.57 & $\mathbf{2 . 0 3}$ & 1.66 & 1.51 & 1.43 & 1.39 & 1.35 \\
\hline Method II & 1.95 & $\mathbf{1 . 6 2}$ & 1.51 & 1.46 & 1.43 & 1.42 & 1.40 \\
\hline Method II (1) & 1.91 & $\mathbf{1 . 5 9}$ & 1.49 & 1.45 & 1.43 & 1.43 & 1.44 \\
\hline Method III (2) & 2.06 & $\mathbf{1 . 6 6}$ & 1.53 & 1.47 & 1.43 & 1.41 & 1.39 \\
\hline
\end{tabular}

(a) Trial calculation of test voltage ( $\mathrm{n}$ : constant)

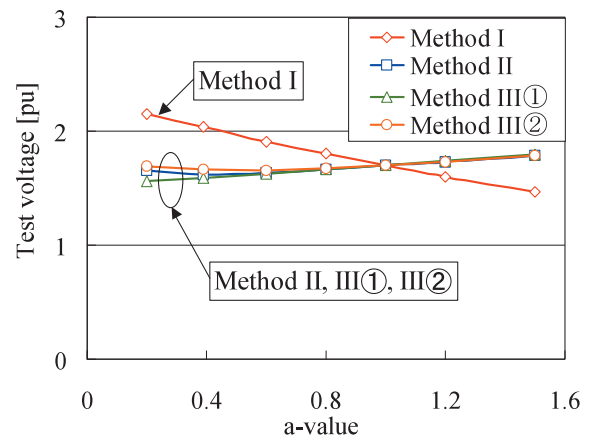

Test voltage for a-value [pu]

\begin{tabular}{|c|c|c|c|c|c|c|c|}
\hline a-value & 0.2 & $\mathbf{0 . 3 9}$ & 0.6 & 0.8 & 1.0 & 1.2 & 1.5 \\
\hline \hline Method I & 2.15 & $\mathbf{2 . 0 3}$ & 1.91 & 1.80 & 1.70 & 1.60 & 1.47 \\
\hline Method II & 1.66 & $\mathbf{1 . 6 2}$ & 1.64 & 1.67 & 1.70 & 1.73 & 1.79 \\
\hline Method III (1) & 1.56 & $\mathbf{1 . 5 9}$ & 1.63 & 1.66 & 1.70 & 1.74 & 1.79 \\
\hline Method III (2) & 1.69 & $\mathbf{1 . 6 6}$ & 1.66 & 1.67 & 1.70 & 1.73 & 1.78 \\
\hline
\end{tabular}

(b) Trial calculation of test voltage (m: constant)

図 $2 \mathrm{a}$ 值を変化させた時の各評価手法による 試験電圧值の試算結果

Fig. 2. Trial calculation of test voltage with changing avalue by reliability evaluation method.

信頼度評価の条件については, 電協研 ${ }^{(3)}$ の条件に従い, 寿 命期間に打いて発生する一線地絡事故： $1.25 \mathrm{pu} ， 2$ 秒， 100 回, 負荷遮断：1.43 pu, 1 秒, 3 回とし, ワイブルパラメータ $\mathrm{n}=30, \mathrm{~m}=11.75, \mathrm{a}=0.39$ とする。試験中の絶縁信頼度 $R_{t}=98 \%$ として，運転期間中の絶縁信頼度 $R_{s}=99.8 \%$ を 満足することを条件とする。検討のために $\mathrm{n}=\mathrm{m} / \mathrm{a}$ の関係 式に従い $\mathrm{n}$ または $\mathrm{m}$ 值を一定として, a 值をパラメータと する試験電圧評価值を求めた。

$a=0.39$ での試験電圧評価結果（図 2 太枠）は，独立事 象法 (従来法) で $2.03 \mathrm{pu}$ に対し, 累積故障法では $1.62 \mathrm{pu}$, 残存確率法では最大で $1.66 \mathrm{pu}$ ，最小で $1.59 \mathrm{pu}$ となる。即 ち, 試験電圧評価值の大小関係は, 独立事象法（従来法）> 残存確率法（高い電圧が先行）> 累積故障法 > 残存確率法 （低い電圧が先行）となる。 $\mathrm{n}=\mathrm{m} / \mathrm{a}$ の関係式に従って $\mathrm{a}$ 值 を変化させた場合， $\mathrm{a}=1$ (偶発故障形)では 3 つの方法によ
る評価值は一致し, $\mathrm{n}$ 值一定で $1.43 \mathrm{pu}, \mathrm{m}$ 值一定で $1.70 \mathrm{pu}$ となる。 $0.8<\mathrm{a}<1.2$ では, 3 つの方法による評価值の差 は小さく, 評価法の中では独立事象法（従来法）による評 価值が $\mathrm{a}=1$ を境に逆転して最大, 最小值を与え, $\mathrm{n}$ 值一定 では $1.39 \sim 1.51 \mathrm{pu}, \mathrm{m}$ 值一定では $1.60 \sim 1.80 \mathrm{pu}$ の範囲で ある。 $\mathrm{a} \ll 1$ (初期故障形) の場合, 独立事象法 (従来法) の結果が最も厳しい評価值となり, 各手法による評価值の 大小関係は先の $\mathrm{a}=0.39$ の場合の通りである。 $\mathrm{a}>1$ (磨 耗故障形）の場合は， $\mathrm{a}<1$ の場合と大小関係が逆転する。 現在の長時間商用周波耐電圧試験においては, 油入変圧 器およびGISにおいて $\mathrm{a} \leqq 1$ が採用されており (1)，独立事 象法（従来法）による試験電圧評価值は，累積故障法を採 用した場合よりも厳しい試験条件を与えていることになる。 独立事象法（従来法）は電圧の印加履歴が残らないモデル であるが，累積故障法は電圧の印加履歴を考慮したモデル であるため，機器の物性を踏まえた上で評価式を選定する 必要があり，4 章で検討する。

\section{4. 電力機器の絶縁特性と信頼度評価法}

〈4・1〉機器の絶縁要素 絶縁材料の形態としては, 気 体，液体，固体，真空などがあり，それぞれの絶縁耐力や 各種条件下での絶縁特性は大きく異なっている。また同じ 気体でも, 大気と高気圧 $\mathrm{SF}_{6}$ ガスでは絶縁耐力の大きさや 電界分布に対する特性は大きく異なり, 同じ大気でも平等 電界と不平等電界の特性は区別すべきものである。この耐 力も雷インパルスと $\mathrm{AC}$ では絶縁種類により相対比が異な るといったこともあり, 破壞のモード, 繰り返しや温度に 対する特性など，様々である。また，実際の機器では，絶 縁材料は単体で用いられるより複合的な構成で用いられる ことが多く，特有な性質を有する ${ }^{(1)}$ 。その絶縁特性に，機 器に加わる電圧ストレス・機械ストレス・熱ストレスなど を考慮し, 所要信頼度を得るよう試験電圧は決められてい る $^{(12)}$ 。

本論文では主要な機器で絶縁材料や構造の対照的なもの として, GIS と油入変圧器を考える。GIS の主要な絶縁要 素には，ガスギャップ，エポキシスペーサ沿面，スペーサ内 部抢よび中心導体やシールド電極との界面などがある。清 浄状態では基本的に同軸円筒構造で，電界利用率が 0.4 0.6 程度の準平等電界であるが，その製造・据付・運用時に 異物混入・発生があれば，絶縁特性は大きく異なったもの となる。また油入変圧器の主要な絶縁要素は, コイル間の 主絶縁, タンク絶縁，リード絶縁，コイル内の絶縁などが あり, 油浸紙絶縁構造から区別すると油道バリア, ターン 間絶縁，セクション間絶縁，油長ギャップなどとなる。

〈4·2〉 絶縁媒体・構造と絶縁特性 GIS および油入 変圧器の主要な絶縁構造を中心に, 比較のため $\mathrm{CV}$ ケーブ ルに用いられる架橋ポリエチレンを加えて, 各種絶縁構造 の AC に対する絶縁特性，およびその試験法の観点からの 信頼度評価を表 3 に示す。特に実験で得られるワイブル分 布の時間形状パラメー夕 $\mathrm{a}$ 值以外に, 実験時間と過電圧や 


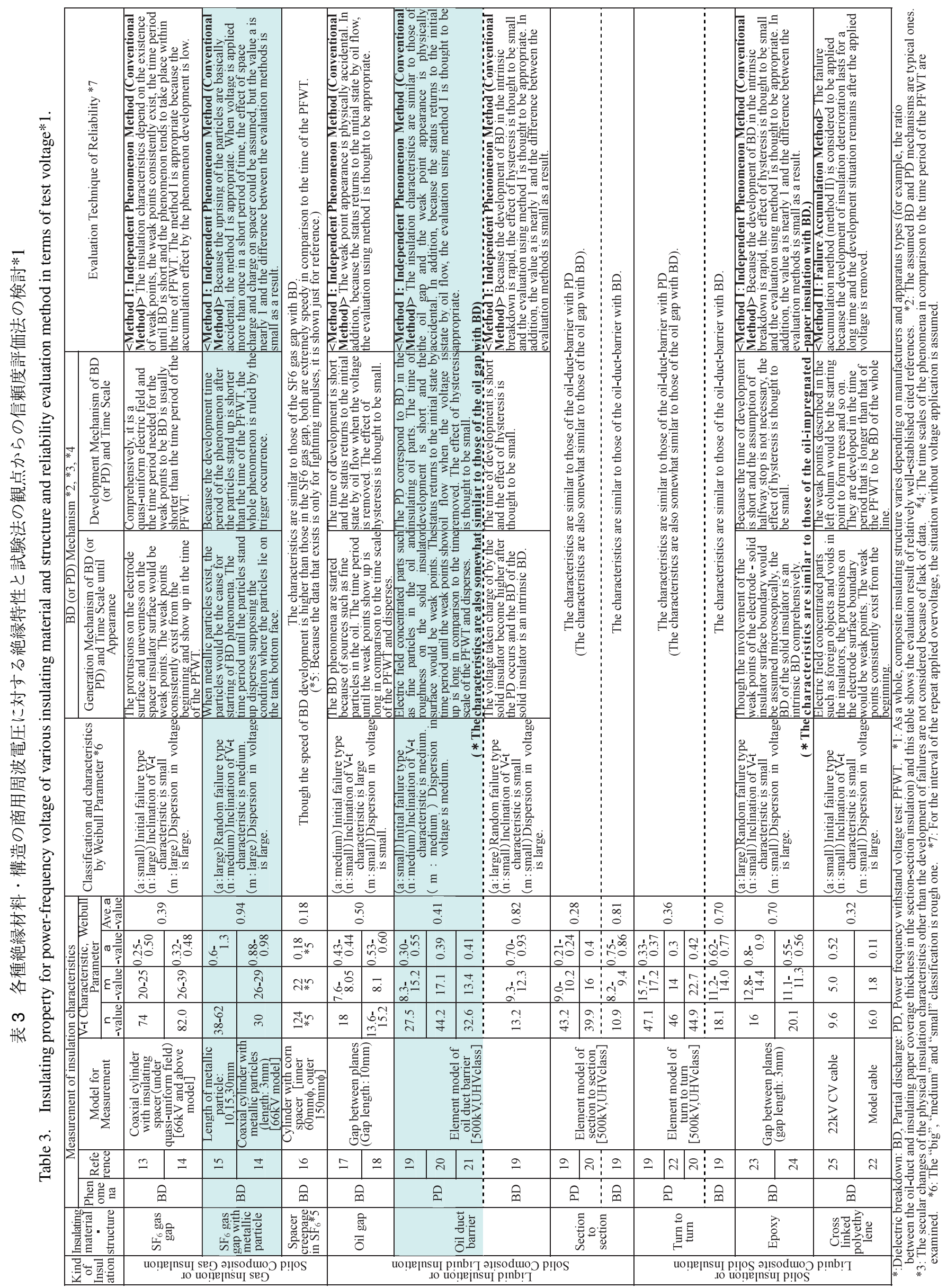


試験電圧の継続時間のスケールの大小を考慮した。なおこ れらは実器を念頭に想定される主なケースであり，学問的 な厳密な追求とは異なるものである。本目的に適切な絶縁 特性の把握は大変重要な課題(7)であり, 別途新デー夕の取 得も含め深遠な検討が必要である。ここでは現状の代表値 である JEC-0102 (1) 制定時の值に準拠した。

GIS 中の絶縁要素の $\mathrm{SF}_{6}$ 絶縁では, ギャップ (清浄時) と異物存在時では, 絶縁破壞電圧のみならずワイブルパラ メータの特徵も大きく異なることがわかる。油ギャップの 絶縁破壞・油道バリアの部分放電・ターン間絶縁の部分放 電・セクション間絶縁の部分放電には共通点が見られ，ま た油道バリアの絶縁破壞・ターン間絶縁の絶縁破壞・セク ション間絶縁の絶縁破壊の特性も類似しているが, 今回の 条件のエポキシの絶縁破壞も似ているとも言える。架橋ポ リエチレンの絶縁破壊が唯一（物性の真性的特徵で他材料 と比してという意味で無く, 機器製造・品質管理技術やモ デル構造・スケールの差異を含めて今回の調査の中ではと いう事であるが)，絶縁劣化進展が蓄積される絶縁破壞义カ ニズムであった。架橋ポリエチレンの $\mathrm{a}$ 值は 0.32 で 1 よ りずっと小さく, 一見すると劣化蓄積タイプと逆の上うに 思えるが，a 值の測定値には絶縁破壞開始のばらつきと進 展時間の遅れの両者が混じり合って現れている可能性があ る。絶縁破壊の開始から進展時間（時間遅れ）と印加電圧 継続時間の大小関係という観点からは, 時間領域が雷イン パルスであるが，標準雷インパルス波形への等価換算評価 時に, $\mathrm{SF}_{6}$ ギャップ・油ギャップの絶縁破壊はあるレベル 以上の電圧継続時間全てを合計し, ターン間絶縁の絶縁破 壊ではある 1 波のみであるレベル以上の電圧継続時間に着 目することと共通点がある ${ }^{(26) 。 ~}$

$\langle\mathbf{4} \cdot \mathbf{3}\rangle$ 試験法の観点からの信頼度評価法の考察 前 述のように本目的に直接応える絶縁物性の整備は現状では 困難な状況であるが, 工学的見地からある程度の推測と不 明時は安全側に評価することを基本に論を進める。従って 評価結果は結論でなく, 現時点での可能性を示している。

GIS は何らかの原因により数 $\mathrm{mm}$ 程度以内の金属性異物 が混入することを想定して設計される。即ち清浄な状態で はかなり絶縁耐力に裕度がある。従って, 表 3 の「 $\mathrm{SF}_{6}$ ガ スギャップ金属異物混入」の項目（上部の網掛け）に着目す る。今回の異物形態（電極上垂直固定配置などでなく, 夕 ンク底面水平置き) では部分放電開始後, 即絶縁破壊を生 じる ${ }^{(14)}$ か, 短時間で絶縁破壊を生じており ${ }^{(15)}$, 両者のワイ ブルパラメータは大差ないため, 絶縁破壊特性と部分放電 開始特性を区別しない。表 3 より a 值は 0.94 であるが，異 物起立などが偶発的な現象として表われていると考えられ る。現象が偶発的であるので, 独立事象法 (従来法) と累積 故障法のどちらの方法でも同様な計算結果を与えるが, 先 行する印加電圧による空間電荷や带電の影響は小さい場合 が多いと想定されるため電圧印加が終了するごとにリセッ トされるという意味合いからは独立事象法 (従来法) で評 価することが考えられる。
油入変圧器は $\mathrm{AC}$ で決定される主要部位は油道バリア構 造であるため, 表 3 の「油道バリア」の項目（下部の網掛 け）に着目する。この構造ではまず油ギャップで部分放電 が開始し長時間商用周波耐電圧試験でも部分放電で合否判 定するので，部分放電特性を用いる。表 3 より a 值は 0.41 であるが，これは油中浮遊粒子などがトリガーとなる弱点 破壞現象を表わしている。しかしながら，この弱点の出現 時間は AC 試験時間スケールより長めでばらつく。また進 展の時間は短く, 電圧が除かれると油流により初期の状態 に戻り履歴の影響は小さいと考元られる。独立事象法（従 来法）による評価は $\mathrm{a}$ 值が 1 より小さい場合に, 他の評価 法と比較して安全側となる高めの試験電圧值を与えること をからも, 独立事象法 (従来法)による評価が考えられる。 今回は各機器の基礎絶縁特性として定評のある文献デー 夕をべースとしたが, 必ずしも実機器と等価とは言えない 場合もある。今後は，モデルとしては実機器の絶縁破壊進 展を等価的に表現するモデル, 材料の経年劣化特性も考慮 したモデル, 試験条件としては印加電圧の前歴の影響（先 行過電圧, 過電圧インターバルの低電圧など) ・過電圧継続 時間と同等の時間領域の考慮, における基礎絶縁特性など の取得が必要と考えられる。

\section{5. あとがき}

電力機器の絶縁仕様である「商用周波耐電圧試験」策定 の際，ワイブル分布関数を用いて信頼度評価が行なわれる が, 複数の電圧レベルが混在する場合に対して課題が提起 されている。本報告では, 最初に複数の電圧レベル混在時 のワイブル評価の各種手法を物理的意味と対応付けて整理 し, 次に各手法の試験電圧レベルへの影響を試算した。更 に, 電力機器の各種絶縁媒体・絶縁構造に対し, 絶縁破壞 または部分放電開始メカニズムから, 適切な評洒法を検討 した。

以下の結果を得た。

（1） 3 種類の信頼度評価法の物理的意味合いを明らか にし, 各電圧レベル下での故障確率密度関数・累積故障確 率を定式化した。JEC-0102 の方法は独立事象を前提とし, その他に対極的な方法として故障進展の累積を前提とする ものがある。

（2）上項をベースに, 複数の電圧印加時の長時間商用 周波耐電圧試験の短時間部の計算式を定式化し, 各方法に おけるワイブルパラメータ值の試験電圧への影響を試算し た。独立事象を前提とする従来法は, 時間形状パラメー夕 a が 1 より小さい条件では, 最も高い試験電圧を与えた。

(3) 電力機器の各種絶縁媒体・絶縁構造に対し, 絶縁 破壊または部分放電開始の開始および進展メカニズムから， 信頼度評価法を検討した。現状利用できるデータから工学 的に評価すると GIS · 油入变圧器とも独立事象法 (従来法) が考えられる。

上記課題に関しては, 微細なメカニズムは明確ではなく, また利用できる絶縁特性デー夕も直接応える条件下のもの 
では無いが，本論文が今後の議論やデー夕取得の参考にな れば幸いである。

(平成 18 年 7 月 27 日受付, 平成 19 年 3 月 30 日再受付)

\section{文献}

(1) 「試験電圧標準」,JEC-0102-1994

(2)「試験電圧の考方方と過電圧」, 電気学会技術報告, No.517 (1994)

（3）電気協同研究会：「絶縁設計の合理化」, 電気協同研究, Vol.44, No.3 (1988)

(4) H. Hirose: "A Consideration on Mathematical Models Applied for Longterm V-t (Voltage-lifetime) Characteristics", T. IEE Japan, Vol.106-A, No.4, pp.185-192 (1985-4) (in Japanese)

広瀬英雄：「長時間 V-t（電圧-時間）特性に用いられる数学モデル についての一考察」, 電学論 A, 106, 4, pp.185-192 (1985-4)

(5) S. Okabe, E. Zaima, and T. Kouno: "Reliability Evaluation of Insulation of Substation Equipment by Weibull Distribution Function", T. IEE Japan, Vol.113-A, No.11, pp.791-792 (1993-11) (in Japanese) 岡部成光・財満英一・河野照哉：「ワイブル分布関数による変電機器の 絶縁の信頼度評価について」, 電学論 A, 113, 11,pp.791-792 (1993-11)

（6）「66 154 kV（非有効接地系統）の絶縁合理化の可能性」,電気学会技 術報告, No.990 (2004)

(7) T. Takuma: "Consideration on AC (Power-Frequency) Insulation Tests for High Voltage Power Equipment", IEEJ Trans. PE, Vol.124, No.7, pp.977983 (2004-7) (in Japanese)

宅間 董:「電力機器の交流絶縁試験に対する考察」, 電学論 B, 124 7, pp.977-983 (2004-7)

(8) H. Goshima, M. Yashima, T. Shindo, and T. Takuma: "Feasibility of Replacement Postponement Based on Insulation Test for Aged Gas-Insulated Power Equipment", IEEJ Trans. PE, Vol.126, No.7, pp.694-700 (2006-7) (in Japanese)

五島久司・八島政史・新藤孝敏・宅間 董:「経年ガス絶縁機器の絶縁試 験によるリプレース時期延伸の可能性」, 電学論 B, 126, 7, pp.694-700 (2006-7)

(9) H. Hirose: "On The Relation Between The Weibull Distribution and The Inverse Power Law in The Long-term V-t Characteristics", T. IEE Japan, Vol.106-A, No.12, p.598 (1986-12) (in Japanese)

広瀬英雄: 「長時間 V-t 特性におけるワイブル分布と逆 $\mathrm{n}$ 乗則との 関係について」, 電学論 A, 106, 12, p.598 (1986-12)

(10) H. Hirose: "Theoretical Foundation for Residual Lifetime Estimation", $T$ IEE Japan, Vol.116-B, No.2, pp.168-173 (1996-2)

(11) S. Okabe, N. Hayakawa, H. Murase, H. Hama, and H. Okubo: "Common Insulating Properties in Insulating Materials", IEEE Trans. Dielect. Elect. Insulation, Vol.13, No.2, pp.327-335 (2006)

(12) H. Murase, S. Okabe, T. Kumai, H. Takakura, M. Takahashi, and H. Okubo: "Systematization of Insulation Design Technology for Various Electric Power Apparatus", IEEE Trans. Dielect. Elect. Insulation, Vol.13, No.2, pp.400-407 (2006)

(13) C.M. Cooke: "Time Dependence of Breakdown in Compressed $\mathrm{SF}_{6}$ ", CIGRE SC15 WG03 15-76 (1976)

(14） 岡庭 潔 - 財満英一 - 青柳浩邦 - 小山 博 - 大久保仁 -上原京一 $\lceil\mathrm{GIS}$ 実機モデル（66 kV 母線）の長時間 V-t 特性」,電気学会全国大 会, No.1173, p.1534 (1988)

(15) T. Hattori, M. Honda, H. Aoyagi, N. Kobayashi, and T. Terasaka: "A Study on Effects of Conducting Particles in $\mathrm{SF}_{6}$ GAS and Test Methods for GIS", IEEE, 84WM 155-8 (1984)

(16) S. Okabe, T. Ohno, E. Zaima, K. Kobayashi, T. Yamagiwa, and F. Endo: "Surface Insulation Characteristics of a GIS Spacer Model for Repeated Impulse Voltage", T. IEE Japan, Vol.115-B, No.2, pp.187-193 (1995-2) (in Japanese)

岡部成光 $\cdot$ 大野高宏 $\cdot$ 財満英一 - 小林健三 $\cdot$ 山極時生 $\cdot$ 遠藤奎将 「GIS スペーサ沿面モデルの繰り返しインパルス絶縁特性」電学論 B, 115, 2, pp.187-193 (1995-2)

(17) M. Ikeda, S. Menju, and H. Murano: "Breakdown Probability Distribution and V-t Characteristics of Transformer", T. IEE Japan, Vol.95-B, No.11, pp.555-562 (1975-11) (in Japanese)

池田正巳 - 毛受新一 - 村野 稔：「変圧器油の絶縁破壊確率分布と V-t 特性」, 電学論 B, 95, 11, pp.555-562 (1975-11)

(18) M. Ikeda, T. Inoue, and T. Yanari: "Wide-Time Region Equiprobabilistic Breakdown V-t Characteristic of Transformer Oil", T. IEE Japan, Vol.101B, No.9, pp.564-568 (1981-9) (in Japanese)

池田正已 ·井上 保 · 矢成敏行 : 「変圧器油の広時間帯域等破壞確率 V-t 特性」, 電学論 B, 101, 9, pp.564-568 (1981-9)
(19) M. Ikeda, T. Inoue, and T. Yanari: "V-t Characteristics and Probabilistic Distribution of Partial Discharge and Breakdown Voltages for Transformer Insulation", T. IEE Japan, Vol.101-B, No.10, pp.571-578 (1981-10) (in Japanese)

池田正巳 · 井上 保 - 矢成敏行 : 「変圧器複合絶縁強度の確率分布と V-t 特性」, 電学論 B, 101, 10, pp.571-578 (1981-10)

(20) E. Zaima, S. Okabe, T. Ohno, Y. Taniguchi, and H. Murase: "AC V-t Characteristics of Core Type Transformer Insulation Model", T. IEE Japan, Vol.115-B, No.4, pp.375-381 (1995-4) (in Japanese) 財満英一・岡部成光 $\cdot$ 大野高宏・谷口安彦・村瀬 洋 : 「内鉄形変圧 器絶縁モデルの交流 V-t 特性」, 電学論 B, 115, 4, pp.375-381 (1995-4)

(21) S. Okabe, T. Ohno, E. Zaima, A. Kishi, K. Aono, and N. Hosokawa: "AC $\mathrm{V}$-t and Impulse V-N Characteristics of Shell-Form Transformer Insulation Model", T. IEE Japan, Vol.115-B, No.4, pp.394-400 (1995-4) (in Japanese) 岡部成光・大野高宏・財満英一: 「外鉄形変圧器絶縁モデルの交流 V-t 特性とインパルス V-N 特性」, 電学論 B, 115, 4, pp.394-400 (1995-4)

(22) 「電力機器 - 絶縁材料技術の横断的評価と共通技術の体系化」, 電気 学会技術報告, No.945 (2003)

(23) M. Honda, H. Aoyagi, M. Koya, N. Kobayashi, and M. Tamura: "V-t Characteristics of epoxy mold insulation for sustained AC voltage", IEEE Trans. $P D$, Vol.PAS-103, No.5 (1984-5)

(24) S. Aoyagi, S. Yamada, H. Murase, I. Ohshima, and T. Iida: "V-t characteristics of GIS Insulating Spacer Model for a Sustained AC Voltage", 9th ISH, pp.1923-1926 (1995)

(25) K. Ohata, G. Katsuta, Z. Iwata, Y. Maruyama, Y. Sekii, and M. Kanaoka: "A Study on Long-Term Characteristics of XLPE Cables", T. IEE Japan, Vol.112-B, No.9, pp.821-824 (1992-9) (in Japanese) 大畠勝一 勝田銀造 - 岩田義輔 · 丸山義雄 · 関井康雄 · 金岡 護 : 「CV ケーブルの長期絶縁特性に関する検討」, 電学論 B, 112, 9, pp.821-824 (1992-9)

(26) S. Okabe, S. Yuasa, M. Koto, and E. Zaima: "Evaluation of lightning surge waveform for LIWV reduction of substation equipment", 13-ISH P.05.66 (2003)

岡 部 成 光 (上級会員) 1986 年 3 月東京大学大学院工学研

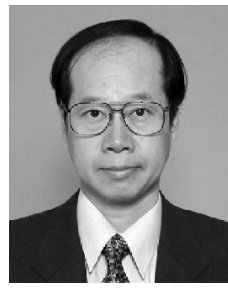
究科電気工学専攻博士課程修了。同年 4 月，東京 電力 (株) 入社。1 1992 年ミュンヘン工科大学客員 研究員。現在，技術開発研究所高電圧・絶縁技術 グループマネージャー。工学博士。IEEE 会員。

坪 井 敏 宏 (正員) 1999 年 3 月東京工業大学大学院理工学

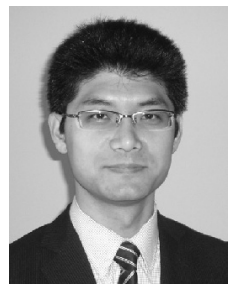
研究科修士課程修了。同年 4 月，東京電力（株） 入社。現在，技術開発研究所高電圧・絶縁技術グ ループ所属。主として送変電設備の絶縁協調に関 する研究に従事。

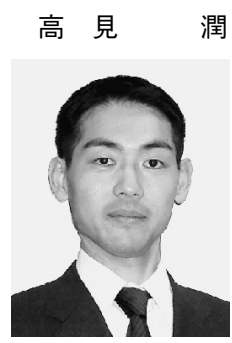

潤（正員） 1997 年 3 月同志社大学大学院工学研究 科電気工学専攻修士課程修了。同年 4 月，東京電 力 (株) 入社。現在, 技術開発研究所高電圧 $\cdot$ 絶 縁技術グループ。主として送変電設備の絶縁協調 に関する研究に従事。 